\title{
Problems Faced by Parents of Differently Abled Children in District Anantnag, Kashmir
}

\author{
Al Sabah Sayeed ${ }^{1}$ and Jasfida Rehman ${ }^{2}$ \\ ${ }^{1}$ Lecturer, ${ }^{2}$ PG Student, Institute of Home Science, University of Kashmir, Jammu \& Kashmir, India \\ E-Mail: asabahsayed@yahoo.com
}

\begin{abstract}
The present study titled 'problems faced by parents of differently abled children in district Anantnag was carried out with the objectives to know about the psychological and social problems faced by parents of differently abled children and to find out about the health and financial problems faced by parents of differently abled children. The sample for the study was 40 parents of differently abled children. Purposive sampling was used to collect the sample and the information was gathered by using a self-designed interview schedule. The results revealed that $57.5 \%$ respondents special children were in the age group of $\mathbf{1 0 - 1 5}$ years, $87.5 \%$ respondents children had disability since birth (i.e. congenital), $80 \%$ respondents had consulted a doctor for immediate measures, $72.5 \%$ respondents were shocked to know about child's disability, $100 \%$ respondents encountered difficulties while sending their children to school, $87.5 \%$ respondents family members were caring towards the special child, $45 \%$ respondents sometimes felt anxious and stressed, $\mathbf{7 5 \%}$ respondents had normal social relationship, $67.5 \%$ respondents felt a need to cut down on their social circle and $60 \%$ respondents said that special child was mostly taken care of by the mother.
\end{abstract}

Keywords: Disability, Psychological Problems, Social Problems, Financial Needs

\section{INTRODUCTION}

Disability is a word often used in daily conversations and holds different meaning for different people. A disability maybe physical, cognitive, sensory, emotional or a combination of these. The ADA defines a person with a disability as (1) having a physical or mental impairment that substantially limits him or her in some major life activity and (2) having experienced discrimination resulting from this physical or mental impairment. Federal regulations define a physical or mental impairment as,

1. Any physiological disorder, or condition, cosmetic disfigurement, or anatomical loss affecting sense organs, respiratory (including speech organs) cardiovascular, reproductive, digestive, genitourinary, haemic and lymphatic, skills and endocrine, or

2. Any mental or physiological disorder such as mental syndrome, emotional or mental illness and specific learning disabilities.

A. Types of Disability: The types of disability may be categorized in the following ways,

1. People who are blind or partially sighted.

2. People with learning or intellectual disabilities.
3. People who are deaf or hearing impaired.

4. People with physical disabilities.

5. People with long term illness.

6. People with mental health or psychological difficulties.

7. People with an acquired brain injury.

\section{B. Problems Faced By Parents of Disabled Children}

When parents learn that their child has a disability, they begin a journey that takes them into a life that is often, filled with a strong emotion, difficult choices, interactions with many different professionals and specialists, and an ongoing need for information and services. Initially, parents may feel isolated and alone, and not know where to begin their search for information, assistance, understanding and support. The impact of having a disabled child is strongly felt in the family. Although having a disabled child affects the whole family major brunt is faced by the parents. They suffer from various problems like psychological, financial, emotional, social, etc.

Children with special needs drain enormous amount of energy, time, and money. For parents having a special child may increase stress, take a toll on mental and physical health, make it difficult to find appropriate and affordable childcare and affect decisions about work, education, training, having additional children and relying on public support. It may be associated with guilt, blame or reduced self-esteem. Marital problems are reported to be present to a greater degree because of lack of time for nurturing the marriage plus the frequent disagreement among parents on what needs to be done for the child.

The couple's time is especially important because there are a number of issues that need to be discussed and dealt with including the feelings of grief and disappointment that sometimes never get processed. A child with physical, intellectual or behavioural disabilities may sometimes hurl the family into crisis, resulting in major conflicts among its members. Family relationships maybe weakened by the added and unexpected physical, emotional and financial stress. Many factors influence the reaction of family including the emotional stability of each member, religious values and beliefs, socio economic status and the severity and the type of child's disability.

The birth of a child with the significant disabilities has a profound impact on the family. The most immediate and 
predictable reaction to the birth of a child with a disability is a shock, characterized by feeling of confusion, anxiety, anger, etc. Fear, anger, guilt and resentment often interfere with couple capacity to communicate and seek realistic solution. An infant with a disability may require more immediate and prolonged attention from mother for feeding, treatment and general care. Thus, her attention may become riveted on the life of the child with disability. The balance that once existed between being a mother and being a partner no longer exists.

The mother may become so involved with caring for the child that other relationships lose their quality and intensity. Further a mother caring for a child who will remain dependent in daily living skills throughout life is at high risk for developing stress and depression. Meanwhile, the father who focuses on financial issues and long term planning rather than taking part in the child's daily living activities maybe avoiding having to deal with the reality of a child with the disability. Fathers who assist with the burden of caring serve as a buffer, contributing to their partner's wellbeing and resilience. Day to day physical and psychological support provided by fathers is invaluable to mothers of children with disabilities.

\section{REVIEW OF LITERATURE}

Raina et al., (2005) in a study of the health and well-being of caregivers of children with cerebral palsy, behavioural issues and the degree of care giving burden had direct, negative effects on caregivers psychological and physical health.

Sen and Yurtsever (2007) carried a study on "difficulties experienced by families with disabled children. The main objective of this study was to determine the difficulties experienced by families with disabled children. The study was carried out in one public and two private rehabilitation centres. The result indicated that the families did not have enough knowledge about their child's condition. Mothers felt severe sadness and indicated that their social life, working life and family relationships were all affected after having a disabled child. Families also faced financial problems.

Tsai and Wang (2009) conducted a study on the relationship between caregiver's strains among mothers with schoolaged intellectually disabled children in Taiwan. Data was collected through face to face interview combined with a structured questionnaire. Instruments employed were the caregiver Strain Index, Social support Scale and open ended questionnaire. In total, 127 mothers completed the questionnaire. Results showed that mothers with intellectually disabled children had a rather high level of strain and received inadequate social support. Social support and strain had a significant and negative status, social support and amount of time spent as a caregiver, as well as the intellectually disabled children's dependent degree of daily living activity, were major predictors of caregiver's strain.
Laskar et al., (2010) carried a study on "Psychological and economic burden on parents of children with locomotor disability" with objectives, to assess the social and financial burden of parents of these children. A cross sectional study was conducted in the Institute for Physically Handicapped (IPH) Delhi and a sample of 100 disabled children having locomotor problems in the age group 6 to 15 years was interviewed. In this study it was found that the parents of the disabled children were severely burdened in terms of financial burden and mental health.

Lakshmi and Anitha (2014) conducted a study on family cohesion and Adaptability among Couples with Differently abled kids in special schools. Study used simple random sampling to collect 50 respondents. Self-prepared questionnaires were used to collect the data constructed and family adaptability and cohesion evaluation scale was also administered to study the same. The results revealed that all respondents were worried about their children's future. Half of the respondents were always burdened by their children. Half of the respondent's social life was not frequently limited, but to some extent they were relaxed. $100 \%$ of the respondents reported that their normal kid's social life was disturbed and they find hard to establish social relationship in a regular pattern. $100 \%$ respondents stated that the disabled kids arrived due to their karma and God's curse. Family cohesion revealed that $60 \%$ had good family cohesion and $40 \%$ of the respondents had poor family cohesion.

\section{RESEARCH METHODOLOGY}

The sample for the present study comprised of parents of differently abled children (either mothers or fathers). The sample size for the present study was 40 . The present study was conducted in district Anantnag. While selecting the sample following criteria were considered.

1. Both males and females were included in the sample.

2. Only parents who had disabled children were selected as sample.

3. Sample was selected from District Anantnag only.

Sample was selected as per purposive sampling that is only those parents were selected whose children were differently abled. The tool used for the study was a self-designed interview schedule. The data collected was carefully coded and then tabulated and percentage was drawn and interpretation was made.

\section{RESULTS AND DISCUSSION}

According to Table I $70 \%$ mothers of the disabled children had normal type of birth and $30 \%$ had caesarean section. $57 \%$ respondents special children were in the age group of $10-15$ years, $27.5 \%$ were in the age group of $15-20 \mathrm{yrs}$, and $15 \%$ respondents said that the special children were in the age group of 5-10 yrs, $87.5 \%$ respondents said that the child's disability was congenital were as $12.5 \%$ said that their children had acquired type of disability. 
TABLE I GENERAL INFORMATION

\begin{tabular}{|c|c|c|}
\hline Type of birth & No. & Percentage \\
\hline Normal & 28 & 70 \\
\hline Caesarean & 12 & 30 \\
\hline Total & 40 & 100 \\
\hline \multicolumn{3}{|c|}{ Age of special child } \\
\hline $5-10$ & 6 & 15 \\
\hline $10-15$ & 23 & 57.5 \\
\hline $15-20$ & 11 & 27.5 \\
\hline Total & 40 & 100 \\
\hline \multicolumn{3}{|c|}{ Child's disability } \\
\hline Congenital & 35 & 85.5 \\
\hline Acquired & 5 & 12.5 \\
\hline Total & 40 & 100 \\
\hline \multicolumn{3}{|c|}{ Type of disability } \\
\hline Physically handicapped & 13 & 32.5 \\
\hline Mentally retarded & 11 & 27.5 \\
\hline Speech problem & 9 & 22.5 \\
\hline Hearing impairment & 7 & 17.5 \\
\hline Total & 40 & 100 \\
\hline \multicolumn{3}{|c|}{ History of disability in the family } \\
\hline Yes & 15 & 37.5 \\
\hline No & 25 & 62.5 \\
\hline Total & 40 & 100 \\
\hline \multicolumn{3}{|c|}{ Age at which child's disability was detected } \\
\hline At birth & 28 & 70 \\
\hline After birth & 12 & 30 \\
\hline Total & 40 & 100 \\
\hline \multicolumn{3}{|c|}{ Immediate measures taken } \\
\hline Doctor consulted & 32 & 80 \\
\hline Saint consulted & 8 & 20 \\
\hline Total & 40 & 100 \\
\hline \multicolumn{3}{|c|}{ Feelings when came to know about child's disability } \\
\hline Shock & 29 & 72.5 \\
\hline Did not believe & 11 & 27.5 \\
\hline Total & 40 & 100 \\
\hline \multicolumn{3}{|c|}{ Reaction of family members } \\
\hline Sympathetic & 25 & 62.5 \\
\hline Normal & 15 & 37.5 \\
\hline Total & 40 & 100 \\
\hline \multicolumn{3}{|c|}{ Difficulty while sending the child to school or any institutiol } \\
\hline Yes & 40 & 100 \\
\hline No & - & - \\
\hline Total & 40 & 100 \\
\hline
\end{tabular}

From Table I 32.5\% children were physically handicapped, $27.5 \%$ were mentally retarded, $22.5 \%$ were suffering from speech disorder and $17.5 \%$ had hearing impairment. $37.5 \%$ respondents said that they had history of disability in the family were as $62.5 \%$ respondents said that they had no history of disability in the family. $70 \%$ respondents said that the child's disability was detected after the birth. $80 \%$ respondents had consulted a saint, $72.5 \%$ respondents were shocked to know, that their child was disabled and $27.5 \%$ respondents did not believe that their child was disabled.

It can be further analyzed from the Table I that $62.5 \%$ respondents said that the family members reacted sympathetically when they came to know about the child disability and $37.5 \%$ respondents revealed that the family members reacted normally when they came to know about their child's disability. $100 \%$ respondents had encountered difficulty while sending their special child to school as there were no special schools available in the locality due to which their children were at home all the time and parents had to take their care on their own, $87.5 \%$ said that the attitude of family members towards their special child was caring and $12.5 \%$ respondents said that the family members perceived their special child as a burden. $100 \%$ respondents said that their family members were supportive.

TABLE II PSychological Problems

\begin{tabular}{|c|c|c|}
\hline Perception about your child's disability & No. & Percentage \\
\hline God's will & 40 & 100 \\
\hline Burden & - & - \\
\hline Unfortunate & - & - \\
\hline Any other & - & - \\
\hline Total & 40 & 100 \\
\hline \multicolumn{3}{|l|}{ Ever felt lonely } \\
\hline Frequently & 25 & 62.5 \\
\hline Sometimes & 5 & 12.5 \\
\hline Rarely & 10 & 25 \\
\hline Total & 40 & 1000 \\
\hline \multicolumn{3}{|c|}{ Become aggressive after the birth of your child } \\
\hline Frequently & 25 & 62.5 \\
\hline Sometimes & 5 & 12.5 \\
\hline Rarely & 10 & 25 \\
\hline Total & 40 & 100 \\
\hline \multicolumn{3}{|c|}{ Life changed after having a special child } \\
\hline Normal & 11 & 27.5 \\
\hline It becomes difficult & 29 & 72.5 \\
\hline Total & 40 & 100 \\
\hline \multicolumn{3}{|l|}{ Habit of crying easily } \\
\hline Sometimes & 28 & 70 \\
\hline Often & - & - \\
\hline Rarely & 5 & 12.5 \\
\hline Never & 7 & 17.5 \\
\hline Total & 40 & 100 \\
\hline \multicolumn{3}{|l|}{ Approach towards life } \\
\hline Life is joyful & 35 & 87.5 \\
\hline Life is full of burden & 5 & 12.5 \\
\hline Total & 40 & 100 \\
\hline \multicolumn{3}{|c|}{$\begin{array}{c}\text { Difficult to control emotion after the birth of your special } \\
\text { child }\end{array}$} \\
\hline Sometime & 26 & 65 \\
\hline Rarely & 8 & 20 \\
\hline Never & 6 & 15 \\
\hline Total & 40 & 100 \\
\hline \multicolumn{3}{|l|}{ Feel anxious and stressed } \\
\hline Sometimes & 18 & 45 \\
\hline Rarely & 10 & 25 \\
\hline Never & 12 & 35 \\
\hline Total & 40 & 100 \\
\hline \multicolumn{3}{|l|}{ Get fatigued easily } \\
\hline Sometimes & 30 & 75 \\
\hline Rarely & - & - \\
\hline Never & 10 & 25 \\
\hline Total & 40 & 100 \\
\hline
\end{tabular}


Further from Table II, it can be interpreted that $100 \%$ respondents perceived their child's disability as God's will. $62.5 \%$ respondents felt lonely frequently, $25 \%$ respondents felt lonely rarely and $12.5 \%$ respondents felt lonely sometimes. $62.5 \%$ respondents become aggressive frequently after the birth of their child, $25 \%$ respondents rarely become aggressive and $12.5 \%$ respondents sometimes become aggressive after the birth of their child. $72.5 \%$ respondents said that their life had become difficult after the birth of their special child and $27.5 \%$ respondents said that their life was normal. $70 \%$ respondents had a habit of crying easily sometimes, $17.5 \%$ respondents had no such habit and $12.5 \%$ respondents were rarely in the habit of crying easily. $87.5 \%$ respondents had joyful approach towards life and $12.5 \%$ respondents perceived their life as full of burden. $65 \%$ respondents sometimes found it difficult to control their emotions, $45 \%$ respondents sometimes felt anxious and stressed and remaining $25 \%$ respondents rarely felt anxious and stressed. $75 \%$ respondents sometimes felt fatigued easily and $25 \%$ respondents never fatigued easily.

TABLE III FinANCIAL PROBLEMS

\begin{tabular}{|c|c|c|}
\hline Source of income & No. & Percentage \\
\hline Husband & 28 & 70 \\
\hline Wives & 7 & 17.5 \\
\hline Relatives & 5 & 12.5 \\
\hline Total & 40 & 100 \\
\hline \multicolumn{3}{|c|}{ Sufficient for your need } \\
\hline Yes & 28 & 70 \\
\hline No & 12 & 30 \\
\hline Total & 40 & 100 \\
\hline \multicolumn{3}{|c|}{ Sufficient for your income } \\
\hline Yes & 32 & 80 \\
\hline No & 8 & 20 \\
\hline Total & 40 & 100 \\
\hline \multicolumn{3}{|c|}{ Taken help from any NGO bank or any other } \\
\hline Yes & - & - \\
\hline No & 40 & 40 \\
\hline Total & 40 & 100 \\
\hline \multicolumn{3}{|c|}{ Need to seek financial help } \\
\hline Sometimes & 20 & 50 \\
\hline Rarely & 13 & 32.5 \\
\hline Never & 7 & 17.5 \\
\hline Total & 40 & 100 \\
\hline \multicolumn{3}{|c|}{ Financial problem because caring for your child } \\
\hline Yes & 10 & 25 \\
\hline No & 30 & 75 \\
\hline Total & 40 & 100 \\
\hline \multicolumn{3}{|c|}{ Need to cut down on expenses } \\
\hline Sometimes & 22 & 55 \\
\hline Never & 10 & 25 \\
\hline Rarely & 8 & 20 \\
\hline Total & 40 & 10 \\
\hline \multicolumn{3}{|c|}{ Anxious about not able to meet child's requirement } \\
\hline Often & 08 & 20 \\
\hline Sometimes & 15 & 37.5 \\
\hline Never & 17 & 42.5 \\
\hline Total & 40 & 100 \\
\hline
\end{tabular}

According to Table III, 70\% respondent's source of income were their husbands, $17.5 \%$ respondents source of income were their wives and $12.5 \%$ respondents source of income were uncles etc. $70 \%$ respondents felt that their income was insufficient for their needs. It can be further analyzed that $80 \%$ respondents supplemented their income by spinning, knitting, expanding their business etc and the remaining $20 \%$ did not try to supplement their income.100\% respondents had not taken help from any NGO. $50 \%$ respondents sometimes need to seek financial help, $32.5 \%$ respondents rarely need to seek financial help and $17.5 \%$ respondents did not felt a need to seek financial help. Further it can be interpreted that $25 \%$ respondents had financial problems because of caring for their special child and $75 \%$ respondents did not encounter any financial problems because of caring for their special child.55\% respondents need to cut down on their expenses and $20 \%$ respondents rarely need to cut down on expenses. $42.5 \%$ respondents were sometimes anxious and $20 \%$ respondents often felt anxious about not being able to meet the child requirements.

TABLE IV Health PRoBlems

\begin{tabular}{|c|c|c|}
\hline Suffering from any health problem & No. & Percentage \\
\hline Hypertension & 14 & 35 \\
\hline Diabetes & 12 & 30 \\
\hline Cardio-vascular problems & 07 & 17.5 \\
\hline None & 07 & 17.5 \\
\hline Total & 40 & 100 \\
\hline \multicolumn{3}{|c|}{ Since when suffering from these problems } \\
\hline After marriage & 8 & 20 \\
\hline After birth of children & 32 & 80 \\
\hline Total & 40 & 100 \\
\hline \multicolumn{3}{|l|}{ Rely on medicines } \\
\hline Everyday & 7 & 17.5 \\
\hline Once in week & 5 & 12.5 \\
\hline Once in 15 days & 12 & 30 \\
\hline Never & 16 & 40 \\
\hline Total & 40 & 100 \\
\hline \multicolumn{3}{|c|}{ Anti-depressant and anti-anxiety drugs } \\
\hline Once in a week & 17 & 42.5 \\
\hline Once in 15 days & 09 & 22.5 \\
\hline Once in a month & 14 & 35 \\
\hline Total & 40 & 100 \\
\hline \multicolumn{3}{|c|}{ Suffer from sleeping disorder } \\
\hline Often & 08 & 20 \\
\hline Sometimes & 14 & 35 \\
\hline Never & 18 & 45 \\
\hline Total & 40 & 100 \\
\hline
\end{tabular}

Table IV, signified that $35 \%$ respondents were suffering from hypertension, $30 \%$ respondents were suffering from 
diabetes, $17.5 \%$ respondents were suffering cardio-vascular problems and the remaining $17.5 \%$ respondents did not suffer from health problems. $20 \%$ respondents were suffering from health problems after their marriage and $80 \%$ were suffering from health problems since the birth of their child. Further it can be analyzed that $40 \%$ respondents never relied on medicines, $30 \%$ respondents had to rely on medicines once in 15 days, $17.5 \%$ respondents had to rely on medicines every day and remaining $12.5 \%$ had to on rely on medicines once in a week. $42.5 \%$ relied on anti-anxiety drugs once in 15 days, 35\% respondents relied on antidepressant and anti-anxiety drugs once in a month. $20 \%$ respondents often suffered from sleeping disorder, $35 \%$ respondents sometimes suffered from sleeping disorders and the remaining $45 \%$ respondents did not suffer from sleeping disorder.

TABLE V SOCIAL PROBLEMS

\begin{tabular}{|c|c|c|}
\hline $\begin{array}{l}\text { Effects of your child on your social } \\
\text { relationship }\end{array}$ & No. & Percentage \\
\hline Normal & 30 & 75 \\
\hline Depression & 10 & 25 \\
\hline Total & 40 & 100 \\
\hline \multicolumn{3}{|c|}{ Time for leisure activities } \\
\hline Yes & 33 & 82.5 \\
\hline No & 7 & 17.5 \\
\hline Total & 40 & 100 \\
\hline \multicolumn{3}{|c|}{ Effect on your marital relationship } \\
\hline Normal & 30 & 75 \\
\hline Tension & 10 & 25 \\
\hline Total & 40 & 100 \\
\hline \multicolumn{3}{|c|}{ Attend social gathering } \\
\hline Yes & 28 & 70 \\
\hline No & 12 & 30 \\
\hline Total & 40 & 100 \\
\hline \multicolumn{3}{|l|}{ Like to visit people } \\
\hline Yes & 26 & 65 \\
\hline No & 14 & 35 \\
\hline Total & 40 & 100 \\
\hline \multicolumn{3}{|c|}{ Like company of others } \\
\hline Yes & 33 & 82.5 \\
\hline No & 07 & 17.5 \\
\hline Total & 40 & 100 \\
\hline \multicolumn{3}{|c|}{ Comfortable with large no. of people } \\
\hline Yes & 31 & 77.5 \\
\hline No & 09 & 22.5 \\
\hline Total & 40 & 100 \\
\hline \multicolumn{3}{|c|}{ Need to cut down on your social circle } \\
\hline Yes & 03 & 7.5 \\
\hline No & 37 & 92.5 \\
\hline Total & 40 & 100 \\
\hline
\end{tabular}

The study is concluded with the fact that parents of differently abled children are facing many problems like psychological, social, economic etc. They were suffering from anxiety, stress, fatigue and many parents also suffered from various ailments like hypertension, diabetes, cardiacproblems etc. Most of the parents having disabled children were not able to meet their requirement and need to cut down on their expenses to make two ends meet.

\section{REFERENCES}

[1] Hardman, M.L; Drew, C.J \& Egan, M.W. (2008). Human Exceptionally - School, Community and Family, $\left(9^{\text {th }}\right.$ Ed) Boston New York Houghton company, 422-428.

[2] Raina P., O’ Donnell, M., Roaenbaum, P., Brehaut, J., Walter, S.D., Rusel, S., Swinton, M., Zhu, B. \& Wood, E. (2005). The health and well-being of caregivers of children with cerebral palsy. Pediatrics, 115(6), 1755.

[3] Sen, E. \& Yurtsever, S. (2007). Difficulties experienced by families with disabled children. Journal for Specialists in Pediatric Nursing. 12(4).

[4] Tsai, S.M \& Wang, H.H. (2009). Relationship between caregivers strain and social support among mothers with intellectually disabled children. Journal of Clinical Nursing. 18(4), 539-48

[5] Laskar, A.R., Gupta, V.K., Kumar, D., Sharma, N. \& Singh, M.M. (2010). Psychological effect and economic burden on parents of children with locomotordisability. Journal of Pediatrics.77, 529-533.

[6] Lakshmi, M. \& Anitha, P. (2014). A study on family cohesion adaptability among couples with differently abled kids in special schools, TrichyDistrict. Indian Journal of Applied Research. 4(12), 119- 22.

From Table V, it can be analyzed that $75 \%$ respondents said social relationships and $25 \%$ respondents said that they suffered from depression and had no interest in social leisure activities while as $17.5 \%$ respondents did not have time for leisure activities. $75 \%$ respondents said that their $25 \%$ had tension bease of their special child $70 \%$ respondents attend social gatherings where as $30 \%$ respondents did not attend any social gatherings. Further it were as $35 \%$ respondents did not like to visit people. $82.5 \%$ respondents liked company of others and the remaining $77.5 \%$ respondent felt comfortable with large number of people was as $22.5 \%$ respondents did not feel comfortable need to cut down on their social circle were as $7.5 \%$ respondents felt a need to cut down on their social circle.

\section{CONCLUSION}

